\title{
Development of a new solid-state absorber material for dye-sensitized solar cell (DSSC)
}

\author{
SWAPNA LILLY CYRIAC ${ }^{1}$, B DEEPIKA ${ }^{1}$, BHASKARAN PILLAI ${ }^{2}, \mathrm{~S} \mathrm{~V} \mathrm{NAIR}^{1, *}$ and \\ K R V SUBRAMANIAN ${ }^{1, *}$ \\ ${ }^{1}$ Amrita Centre for Nanosciences and Molecular Medicine, Ponekkara P.O., Kochi 682 041, India \\ ${ }^{2}$ Department of Radiation Oncology, AIMS, Kochi 682 041, India
}

MS received 20 February 2013; revised 1 April 2013

\begin{abstract}
In contrast to the conventional DSSC systems, where the dye molecules are used as light harvesting material, here a solid-state absorber was used as a sensitizer in conjunction with the dye. The materials like $\mathrm{ZnO}$ and $\mathrm{Al}_{2} \mathrm{O}_{3}: \mathrm{C}$, which will show optically stimulated luminescence (OSL) upon irradiation were used as extremely thin absorber layers. This novel architecture allows broader spectral absorption, an increase in photocurrent, and hence, an improved efficiency because of the mobility of the trapped electrons in the absorber material after irradiation, to the $\mathrm{TiO}_{2}$ conduction band. Nanocrystalline mesoporous $\mathrm{TiO}_{2}$ photoanodes were fabricated using these solid-state absorber materials and after irradiation, a few number of samples were co-sensitized with $\mathrm{N719}$ dye. On comparing both the dye loaded photoanodes $\left(\mathrm{ZnO}^{-\mathrm{TiO}_{2}}\right.$ and $\mathrm{Al}_{2} \mathrm{O}_{3}: \mathrm{C} / \mathrm{TiO}_{2}$ ), it can be concluded from the present studies that, the $\mathrm{Al}_{2} \mathrm{O}_{3}: \mathrm{C}$ is superior to $\mathrm{ZnO}$ under photon irradiation. $\mathrm{Al}_{2} \mathrm{O}_{3}: \mathrm{C}$ is more sensitive to photon irradiation than $\mathrm{ZnO}$ and hence there can be more trap centres produced in $\mathrm{Al}_{2} \mathrm{O}_{3}: \mathrm{C}$.
\end{abstract}

Keywords. Optically stimulated luminescence; DSSC; zinc oxide; carbon-doped aluminium oxide.

\section{Introduction}

The need for alternative energy sources led to tremendous research work particularly those using nanomaterial, in the area of third generation photovoltaic systems to pull the efficiency from reported $11 \cdot 1 \%$ (O'Regan and Grätzel 1991) to the predicted theoretical value of $63 \%$ (Luque and Martin 1997). The most important problems that are faced in the DSSC, leading to low efficiency, are the recombination of the photo-injected electrons (Ghada et al 2008) and the limited spectral absorption range or light harvesting (Gopal et al 2006). Thus, a key to improve the efficiency is to increase the light harvesting property in DSSC, which can be achieved in different ways.

Currently organic dyes (Li et al 2006), semiconductor quantum dots (Nozik et al 2002; Schaller et al 2004), porphyrins (Graetzel et al 2003) or a combination of these forms the light-harvesting component (absorber material) of conventional DSSC's. However, these components still suffer from limitations of average light harvesting efficiencies and lack of lifetime/stability. A promising alternative is to develop a new solid-state absorber material, which upon high-energy irradiation

\footnotetext{
*Author for correspondence (krvsubramanian@aims.amrita.edu; shantinair@aims.amrita.edu)
}

shows OSL (optically stimulated luminescence) property by adequately populating trap levels that can hold electrons for indefinite time. These electrons, which normally luminesce by recombination, are readily available for transport to the semiconductor region (in contact with the OSL layer) upon optical stimulation, thereby increasing the efficiency of the solar cell.

Optically stimulated luminescence (OSL) is the luminescence emitted from a pre-irradiated insulator or a semiconductor during exposure to light. During highenergy irradiation, the absorbed energy is partially transferred to the charges (electrons and holes) thereby creating free charge carriers within the material. Majority of these free carriers are trapped at pre-existing or radiation induced defect sites in the crystal lattice of the material, where they can remain for indeterminate periods of time. During optical stimulation with light, the trapped charges can be moved from the trap state into the conduction band and they recombine, and release energy consisting of luminescent light. Thus, irradiation creates a substantial electron population in the traps of the material (Schembri et al 2007). Materials showing OSL property can absorb wide spectral region because of the new trap centres formed. Combining the OSL material with the dye in DSSC can absorb vast spectral region thereby increasing the light harvesting property in DSSC.

The OSL material will emit luminescence after stimulation. If we quench this luminescence by transporting the 
trapped electrons from OSL material to semiconductor in the DSSC, we can increase the photocurrent even at lower energy stimulation. This OSL material on the working electrode can also act as a barrier layer to avoid the back flow of the electrons, reducing the recombination of the trapped electrons with the holes in the valence band (or holes in the electrolyte), thereby further increasing the efficiency. Materials showing crystal imperfections including point defects or interstitial defects, which can be created during synthesis or by doping, can show OSL property. Hence, OSL is a property of the solid-state material having high thermal and chemical stabilities, low effective atomic number, high sensitivity to radiation, high optical stimulation efficiency and wide bandgap allowing a large variety of stable traps and colour centres (Pradhan et al 2008).

To discuss the solid-state absorber materials chosen for this study, $\mathrm{Al}_{2} \mathrm{O}_{3}: \mathrm{C}$ (carbon-doped $\mathrm{Al}_{2} \mathrm{O}_{3}$ ) and $\mathrm{ZnO}$ was chosen among various potential luminescent materials in view of its excellent OSL properties like low effective atomic number, favourable band width, etc. $\mathrm{Al}_{2} \mathrm{O}_{3}: \mathrm{C}$ emits both RL and OSL in the blue region $(420 \mathrm{~nm}) . \mathrm{ZnO}$ nanophosphors can be used as an OSL material because of the existence of intrinsic or extrinsic defects, high sensitivity and high optical stimulation efficiency as compared with other commercially available OSL materials (Cruz-Vaquez et al 2007). For these reasons, highenergy irradiated $\mathrm{ZnO}$ and $\mathrm{Al}_{2} \mathrm{O}_{3}: \mathrm{C}$ used in conjunction with organic dyes can be strongly considered as promising candidates for the absorber material in the dyesensitized solar cells (DSSC). The DSSC uses $\mathrm{TiO}_{2}$ as the standard semiconducting layer for transport.

In our studies, to improve the efficiency of the current DSSC, the nanocrystalline $\mathrm{ZnO}$ and $\mathrm{Al}_{2} \mathrm{O}_{3}$ doped with carbon were synthesized using sol-gel method. The polycrystalline nanoparticles were coated on the conducting glass substrate and irradiated with ionizing radiation using a linear accelerator. This paper presents the OSL response and photovoltaic studies of the polycrystalline $\mathrm{ZnO}$ material and $\mathrm{Al}_{2} \mathrm{O}_{3}$ doped with carbon.

\section{Experimental}

\subsection{Synthesis of ZnO nanoparticles}

$\mathrm{ZnO}$ colloidal solution was prepared by a simple sol-gel method using zinc acetate dihydrate (extra pure, Merck) and sodium hydroxide (97\%, Fisher Scientific) in methanol (Fisher Scientific) at $51{ }^{\circ} \mathrm{C}$ for $10 \mathrm{~min}$. Sodium hydroxide solution was added drop-wise under high speed stirring for $30 \mathrm{~min}$. The solution was sealed and centrifuged at $11000 \mathrm{rpm}$ for $15 \mathrm{~min}$. As obtained $\mathrm{ZnO}$ nanoparticles (NPs) were ultrasonically cleaned and resuspended with methanol for $1 \mathrm{~h}$. Cleaned colloidal solu- tion of $\mathrm{ZnO}$ nanoparticles (NPs) were spin coated on $\mathrm{TiO}_{2}$ thin film. The overall reaction can be written as:

$$
\begin{aligned}
& \mathrm{Zn}\left(\mathrm{CH}_{3} \mathrm{COO}\right)_{2}+2 \mathrm{NaOH} \rightarrow \mathrm{Zn}(\mathrm{OH})_{2}+2 \mathrm{CH}_{3} \mathrm{COONa}, \\
& \left.\mathrm{Zn}(\mathrm{OH})_{2} \text { (unstable }\right) \rightarrow \mathrm{ZnO} \text { (stable). }
\end{aligned}
$$

By varying the concentration of $\mathrm{NaOH}$, another set of stable $\mathrm{ZnO}$ nanocolloid was prepared.

\subsection{Preparation of $\mathrm{TiO}_{2}$ thin film and $\mathrm{ZnO} / \mathrm{TiO}_{2}$ photoanode}

To form the $\mathrm{TiO}_{2} / \mathrm{ZnO} /$ Ruthenium N719 photoanode structure, a $\mathrm{TiO}_{2}$ (P25, Degussa) paste was prepared in ethanol and was coated on to cleaned fluorinated tin oxide glass (FTO glass, Solaronix) with $80 \%$ transmittance in the visible spectrum) by using a doctor blade technique. The film was calcined at $450{ }^{\circ} \mathrm{C}$ for $30 \mathrm{~min}$ to crystalline anatase form. The fresh $\mathrm{ZnO}$ nanocolloids were used for spin coating on $\mathrm{TiO}_{2}$ mesoporous film at $1800 \mathrm{rpm}$ in air for $5 \mathrm{~min}$.

\subsection{Preparation of $\mathrm{Al}_{2} \mathrm{O}_{3}: \mathrm{C} / \mathrm{TiO} \mathrm{O}_{2}$ photoanode}

About $5 \mathrm{~g}$ of commercially available polycrystalline alumina powder (LR grade, $\mathrm{NiCE}$ ), $\mathrm{Al}_{2} \mathrm{O}_{3}$ was first dissolved in ethoxy ethanol. Then, graphite fine powder (extra pure, Loba Chemie) was added slowly with a doping concentration of about $10000 \mathrm{ppm}$. Once the particles are dissolved in the solvent, the suspensions of $\mathrm{Al}_{2} \mathrm{O}_{3}: \mathrm{C}$ was deposited on $\mathrm{TiO}_{2}$ mesoporous thin film by doctor blade method. $\mathrm{Al}_{2} \mathrm{O}_{3}: \mathrm{C} / \mathrm{TiO}_{2}$ coated photoanode was dried in the furnace at a temperature of $450-500{ }^{\circ} \mathrm{C}$ in static air for $30 \mathrm{~min}$.

\subsection{Irradiation of photoanode}

Optically-stimulated luminescence was studied at room temperature. All measurements were performed in a $20 \times 20 \times 2 \mathrm{~cm}$ black acrylic phantom. The samples were irradiated with $6 \mathrm{MV}$ photon beam and $15 \mathrm{MeV}$ electron beam from an Elekta linear accelerator (Linac) for $25 \times 25 \mathrm{~cm}$ field size. Since, Compton cross-section is more in $6 \mathrm{MV}$ photon beam, it was chosen to create more trap centres in the samples. For $6 \mathrm{MV}$ photon beam, OSL response was investigated for different absorbed doses ( 5 and $6 \mathrm{~Gy}$ ) for each set of photoanode using an SSD technique with a $5 \mathrm{~cm}$ buildup block. $15 \mathrm{MeV}$ electron beam was used only for $\mathrm{ZnO} / \mathrm{TiO}_{2}$ photoanode to deliver a 600 cGy with an appropriate built-up thickness.

\subsection{Cell fabrication}

A set of irradiated samples from both $\mathrm{ZnO}$-coated $\mathrm{TiO}_{2}$ and $\mathrm{Al}_{2} \mathrm{O}_{3}$-coated $\mathrm{TiO}_{2}$ were immersed in $0.3 \mathrm{mM}$ N719 
dye (Solaronix Co. Ltd.) solution for $24 \mathrm{~h}$ of sensitization. The electrodes were dipped in such a way that only a portion of the substrate is sensitized with the dye. Along with the ETA sensitization, these half dye dipped samples will provide enough charge transport to the conduction band of $\mathrm{TiO}_{2}$. So, our complete working electrode contains $\mathrm{TiO}_{2}$-coated on FTO, irradiated $\mathrm{ZnO}$ or $\mathrm{Al}_{2} \mathrm{O}_{3}$ : C thin film sensitized with half dye. Pt-coated FTO was used as counter electrodes and the electrolyte was prepared as reported in the literature (Santiago et al 2009). Working and counter electrodes were sandwiched using a spacer of $60 \mu \mathrm{m}$ thickness. Here, the active area of the cells was within $0.7-0.4 \mathrm{~cm}^{2}$.

\subsection{Analytical techniques}

The prepared $\mathrm{ZnO} / \mathrm{TiO}_{2}$ thin film and $\mathrm{Al}_{2} \mathrm{O}_{3}: \mathrm{C} / \mathrm{TiO}_{2}$ thin-film substrates were characterized using a scanning electron microscope (SEM, JEOL, JSM-6490LA) and X-ray diffractometer (XPERT PRO, P Analytical). The photoluminescence (PL) measurements for both liquid and solid samples were performed with HORIBA, JOBIN YVON fluorometer (Model Fluoro Max 4). UV-Vis spectra were recorded on a PERKIN ELMER $\lambda$-750 spectrophotometer. The particle size was obtained using DLS (NICOMP TM 380 ZLS). The cyclic voltammetric (CV) measurements were performed using Autolab (PGSTAT302N). CV's were recorded at room temperature by employing a three-electrode cell with platinum as a counter electrode, sample as the working electrode and $\mathrm{Ag} / \mathrm{AgCl}$ electrode as the reference electrode. The CV's were obtained by a continuous scanning from $-2 \mathrm{~V}$ to $+2 \mathrm{~V}$ at a scan rate of 0.05 to $0.01 \mathrm{~V} / \mathrm{s}$.

The current-voltage characteristics of the cells were measured using a digital source meter (Keithley Instruments Inc., Model 2420) under simulated AM 1.5 illumination provided by solar simulator (Newport, 92251A1000, Oriel Instruments).

\section{Results and discussion}

The as-deposited film, figure 1(a), shows the amorphous nature of $\mathrm{ZnO}$ nanoparticles. Figure $1(\mathrm{~b})$ shows the XRD of $\mathrm{ZnO}$ film annealed at $300{ }^{\circ} \mathrm{C}$. The high crystallinity of this film shows that the thermal annealing has the effects on narrowing the diffraction peak, indicating that grain growth has occurred. Figure 1(c) shows XRD of $\mathrm{ZnO}$ coated over $\mathrm{TiO}_{2}$. These films were annealed at $100{ }^{\circ} \mathrm{C}$. Peaks corresponding to both $\mathrm{TiO}_{2}$ and $\mathrm{ZnO}$ phases were observed in XRD spectra. The crystalline peaks of $27.77^{\circ}$ and $\left(34.9^{\circ}, 36.7^{\circ}\right)$ correspond to $\mathrm{TiO}_{2}$ anatase and $\mathrm{ZnO}$ structures, respectively. All the peaks matched well with the bulk $\mathrm{ZnO}$, which could be indexed as the zincite structure of $\mathrm{ZnO}(\lambda=1 \cdot 54056$, quality: $C$, JCPDF no. 751526). The crystallinity of this $\mathrm{TiO}_{2} / \mathrm{ZnO}$ composite was lower than that of $\mathrm{ZnO}$ and this may be due to the lower annealing temperature $\left(100{ }^{\circ} \mathrm{C}\right)$. From XRD data, peaks at $34.9^{\circ}$ and $36.7^{\circ}$, confirms the presence of $\mathrm{ZnO}$ nanoparticle formation, which was annealed at $300{ }^{\circ} \mathrm{C}$. But, for the cell measurements, the amorphous $\mathrm{ZnO}$ coated on the $\mathrm{TiO}_{2}$ was used. Though the high temperature treatment of $\mathrm{ZnO}$ thin film helps to improve the crystallinity of the film, it was observed that high temperature treatment initiated sintering of nanoparticles in the film with increase in particle size and also leading to a decrease in active surface area for the adsorption of dye molecule. Since, fine particle size $(<500 \mathrm{~nm})$ is essential for demonstration of OSL property (Schembri et al 2007), the amorphous films were used for further studies and characterization.

In order to understand the uniformity of the coatings, SEM images of the thin films have been made. Figure 2 shows the surface morphology of the porous $\mathrm{TiO}_{2}$ film and $\mathrm{ZnO}$-coated $\mathrm{TiO}_{2}$ film. Figure 2(b) demonstrates the formation of porous $\mathrm{TiO}_{2}$ film, having high surface area. Figure 2(c) shows that thin layer of $\mathrm{ZnO}$ nanoparticles were formed on the surface of $\mathrm{TiO}_{2}$. Using DLS (dynamic light scattering) analysis, the average hydrodynamic diameter for the two different concentrations (1:1 and $1: 1.5)$ of the $\mathrm{ZnO}$ nanoparticles was found to be 17 and $34 \mathrm{~nm}$, respectively (figure 3). The distribution was obtained by using number weighed NICOMP distribution. Figure 4(a) shows the room temperature photoluminescence spectra of $\mathrm{ZnO}$ methanol suspension. The samples were excited at $354 \mathrm{~nm}$. The PL spectra show the emission peaks located at 397 and $544 \mathrm{~nm}$ correspond to UV and green emissions. The UV emission was due to the band-edge recombination of free excitons. The green

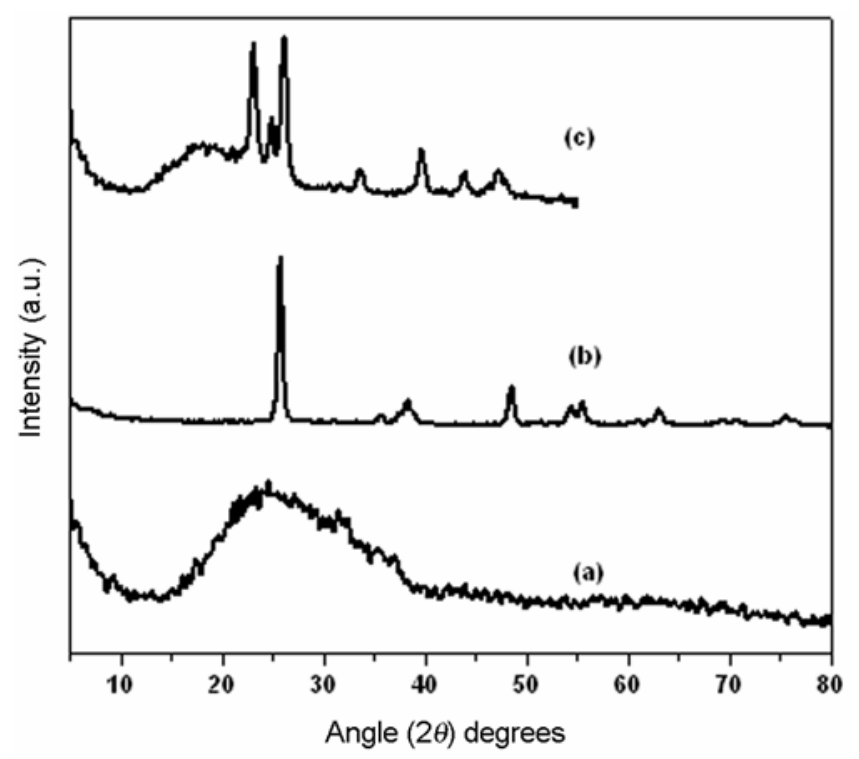

Figure 1. X-ray diffractograms of (a) amorphous $\mathrm{ZnO}$, (b) crystalline $\mathrm{ZnO}$ and (c) $\mathrm{ZnO}$ coated over $\mathrm{TiO}_{2}$. 


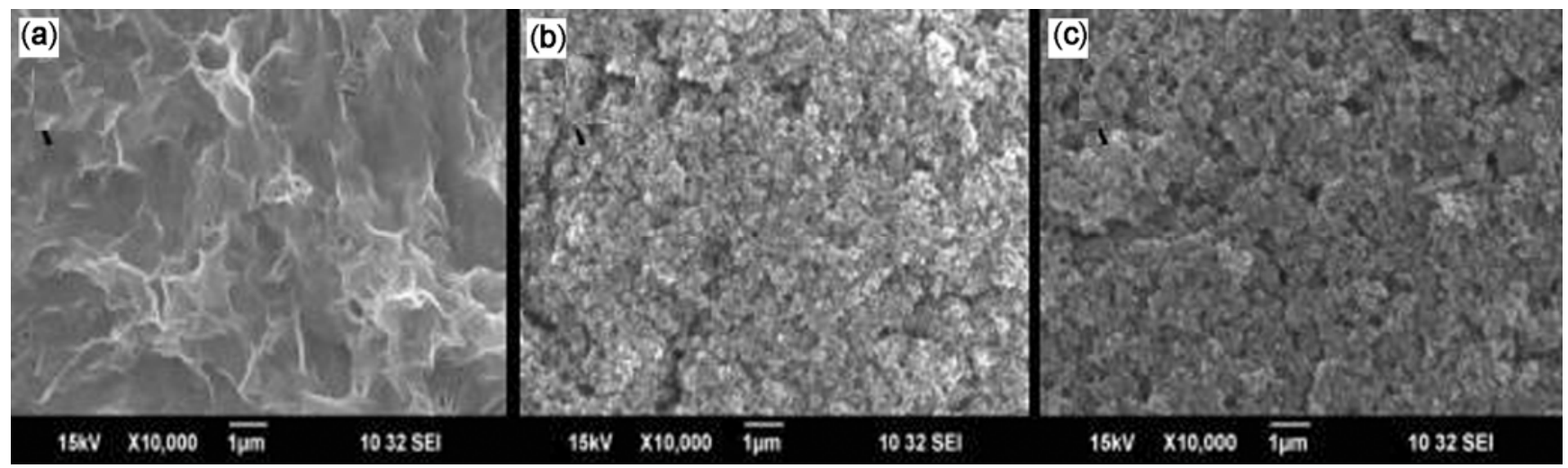

Figure 2. SEM images of (a) $\mathrm{ZnO}$ thin film, (b) mesoporous $\mathrm{TiO}_{2}$ thin film and (c) $\mathrm{ZnO}$ coated $\mathrm{TiO}_{2}$ thin film.

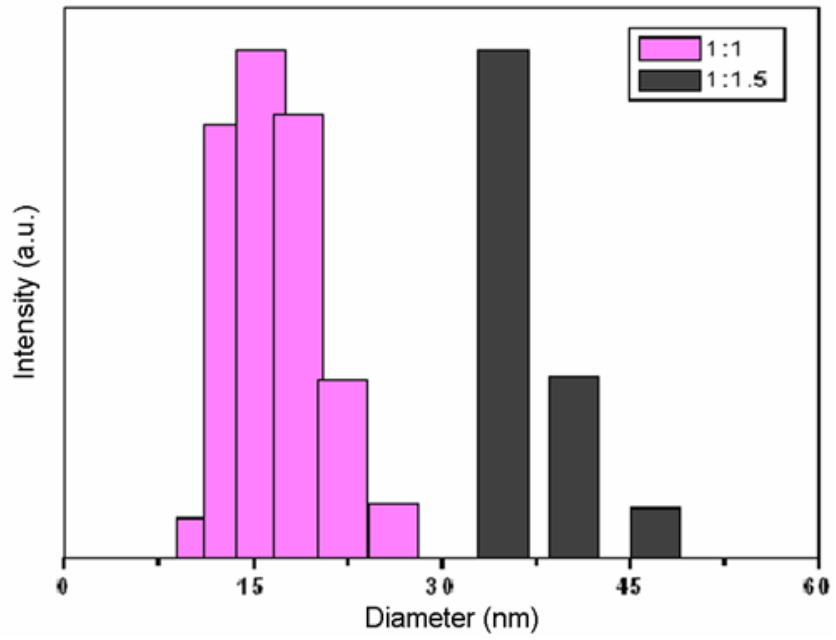

Figure 3. Particle size distribution of $1: 1$ and $1: 1 \cdot 5 \mathrm{ZnO}$ nanocolloids.

emission at $544 \mathrm{~nm}$ was due to the oxygen vacancies and other defects.

The room temperature PL spectra of irradiated and non-irradiated amorphous $\mathrm{ZnO}$ thin film under excitation of $397 \mathrm{~nm}$ are shown in figure 4(b). The samples were irradiated with $15 \mathrm{MeV}$ electron beam to deliver an absorbed dose of 600 cGy (centigray). In the emission spectra of the pristine samples ((a) and (b)), two main peaks were observed at $412 \mathrm{~nm}$ (violet emission) and $540 \mathrm{~nm}$ (green emission). But for the irradiated samples ((d) and (e)) with $15 \mathrm{MeV}$ electron beam, it is observed that the position of the violet emission (412 nm) was affected by irradiation. A broad blue peak around $460 \mathrm{~nm}$ is observed for these samples. There was no shift in the green emission. But in the case of photon-irradiated sample (c), there was no shift in peak positions. On irradiating with $15 \mathrm{MeV}$ electron beam, the knocked out electrons (due to inelastic collision) from the different atomic shells of the $\mathrm{ZnO}$ nanoparticles will be trapped either in these inherent defects centres or will create another defect centre in its electronic structure. As a result, there will be an either increase in the intensity of these inherent defect centre, due to the increased population of electrons in these levels, or will create another colour centre, due to the new defect level, in the PL spectra of $\mathrm{ZnO}$ nanoparticles. Here, the peak at $460 \mathrm{~nm}$ can be due to the new defect centre created by irradiation. The broadening of the peak may be due to the low electron density in that particular level. In addition to that, Compton effect, which is predominant in $6 \mathrm{MV}$ photon beam is not energetically favourable to create radiation induced trap states in the $\mathrm{ZnO}$ lattice. Hence, there was no effect on the PL spectra.

The bandgap of $\mathrm{ZnO}$ nanocolloids was obtained by plotting the graph $(\alpha h v)^{2}$ vs $h v$ (figure 5). It was found that the $\mathrm{ZnO}$ nanocolloid in $1: 1$ ratio has a bandgap of $3.53 \mathrm{eV}$, whereas for $1: 1.5$ ratios, the $E_{\mathrm{g}}$ was reduced to $3.45 \mathrm{eV}$. From the XRD pattern (figure 6 ) of the alumina $\left(\mathrm{Al}_{2} \mathrm{O}_{3}\right)$, graphite and $\mathrm{Al}_{2} \mathrm{O}_{3}: \mathrm{C}$ thin films annealed at $500{ }^{\circ} \mathrm{C}$, a shift in peak for the polycrystalline material doped with carbon was seen. The dopant, carbon, acts as a catalyst for the formation of defects in $\mathrm{Al}_{2} \mathrm{O}_{3}$ lattice. When the doping concentration increases, carbon atoms due to their smaller ionic radii $(0 \cdot 15 \AA)$ occupies the interstitial positions and results in a lateral strain in $\mathrm{Al}_{2} \mathrm{O}_{3}$ lattice. Annealing the sample at $500{ }^{\circ} \mathrm{C}$ helps the fast diffusion of carbon atoms into $\mathrm{Al}_{2} \mathrm{O}_{3}$. In the figure, the $2 \theta$ position at 30.94 of $\mathrm{Al}_{2} \mathrm{O}_{3}$ has been shifted to 29.91, when it is doped with carbon. This negative shift $(\Delta \theta=1.03$ ) could be due to the lateral strain produced by the carbon atom in the $\mathrm{Al}_{2} \mathrm{O}_{3}$ lattice. The high intensity peak of graphite at 26.61 is not seen in the XRD pattern of $\mathrm{Al}_{2} \mathrm{O}_{3}$ : C. This could be due to low doping concentration $(1 \mathrm{wt} \%)$ of carbon atom.

Figure 7 shows the SEM images of $\mathrm{TiO}_{2}$ mesoporous film and $\mathrm{Al}_{2} \mathrm{O}_{3}: \mathrm{C} / \mathrm{TiO}_{2}$ nano-composites. In figure 7(b), the morphology of $\mathrm{Al}_{2} \mathrm{O}_{3}: \mathrm{C}$ is like a sheet on the surface of $\mathrm{TiO}_{2}$ thin film due to the heat treatment at $450-500{ }^{\circ} \mathrm{C}$. The room temperature PL emission spectra of $\mathrm{Al}_{2} \mathrm{O}_{3}: \mathrm{C}$ thin film is shown in figure 8 . All the samples were 


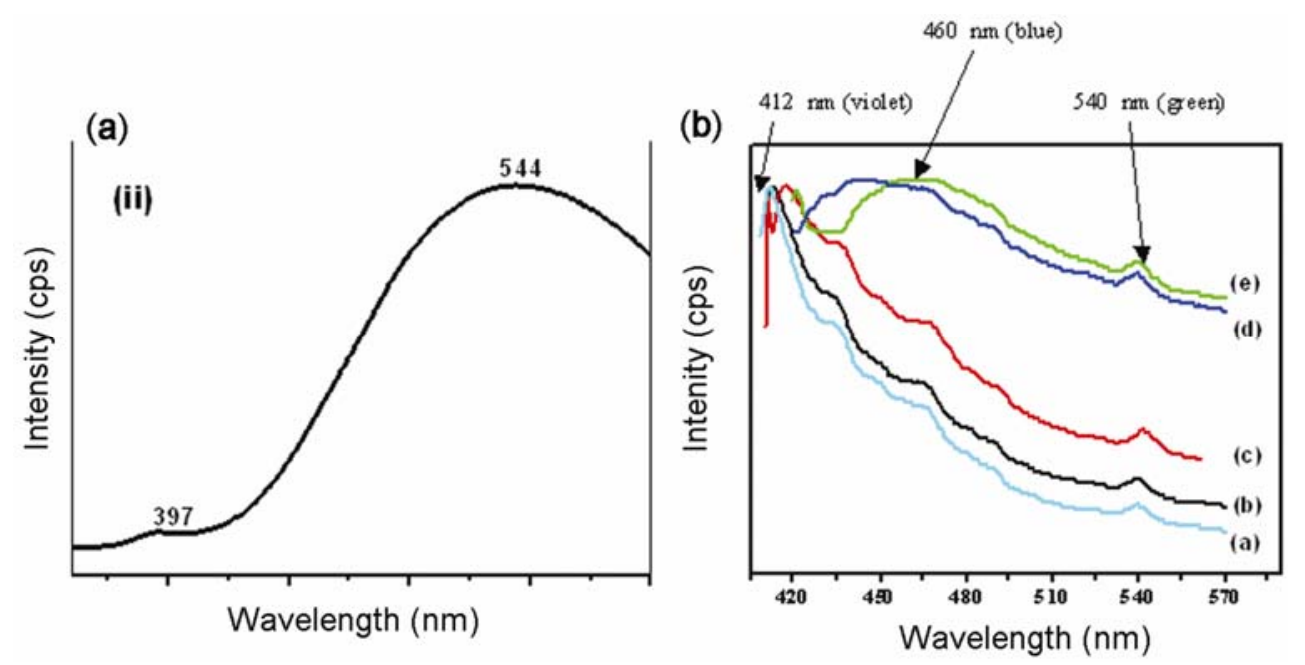

Figure 4. Photoluminescence spectra of (a) $\mathrm{ZnO}$ suspension and (b) $\mathrm{ZnO}$ thin film.

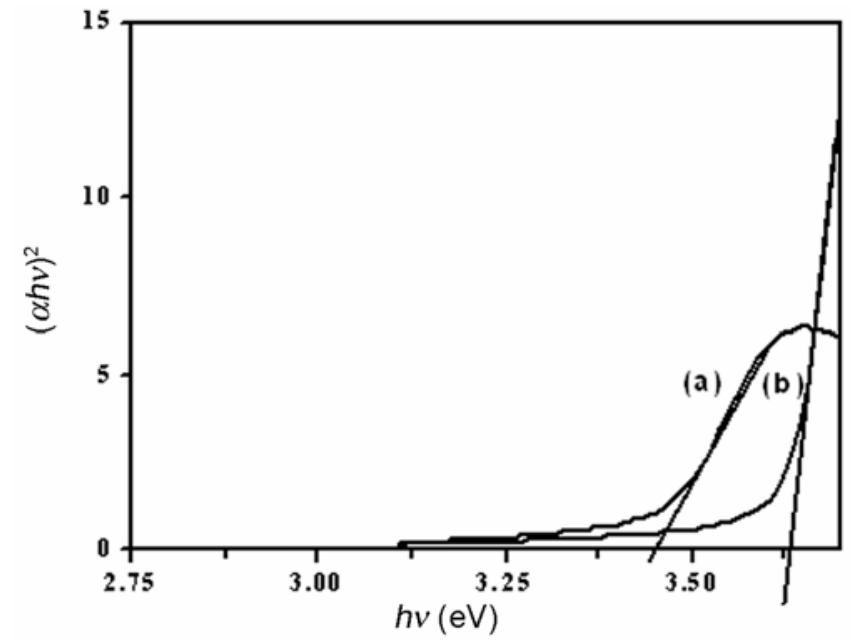

Figure 5. Bandgap determination of $\mathrm{ZnO}$ of colloidal suspension: (a) $1: 1.5$ and (b) $1: 1$.

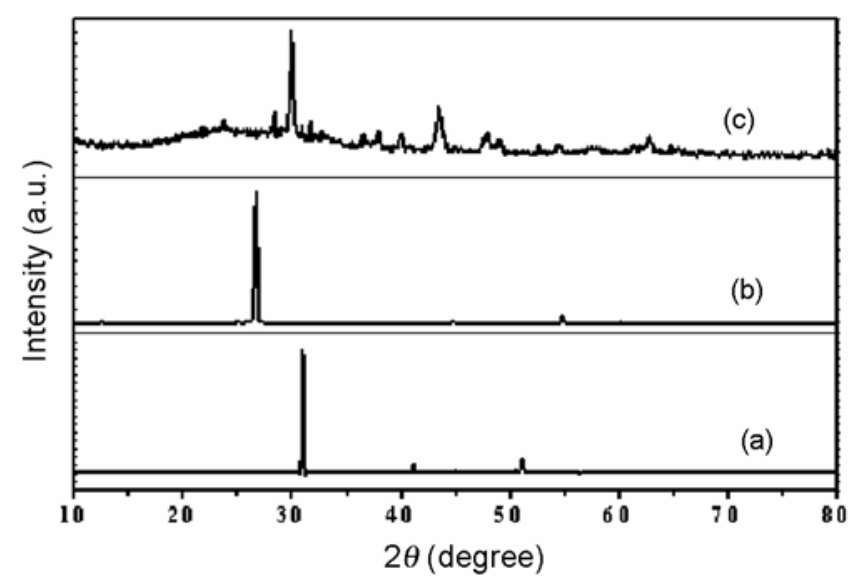

Figure 6. X-ray diffractograms of (a) $\mathrm{Al}_{2} \mathrm{O}_{3}$, (b) graphite and (c) $\mathrm{Al}_{2} \mathrm{O}_{3}: \mathrm{C}$.

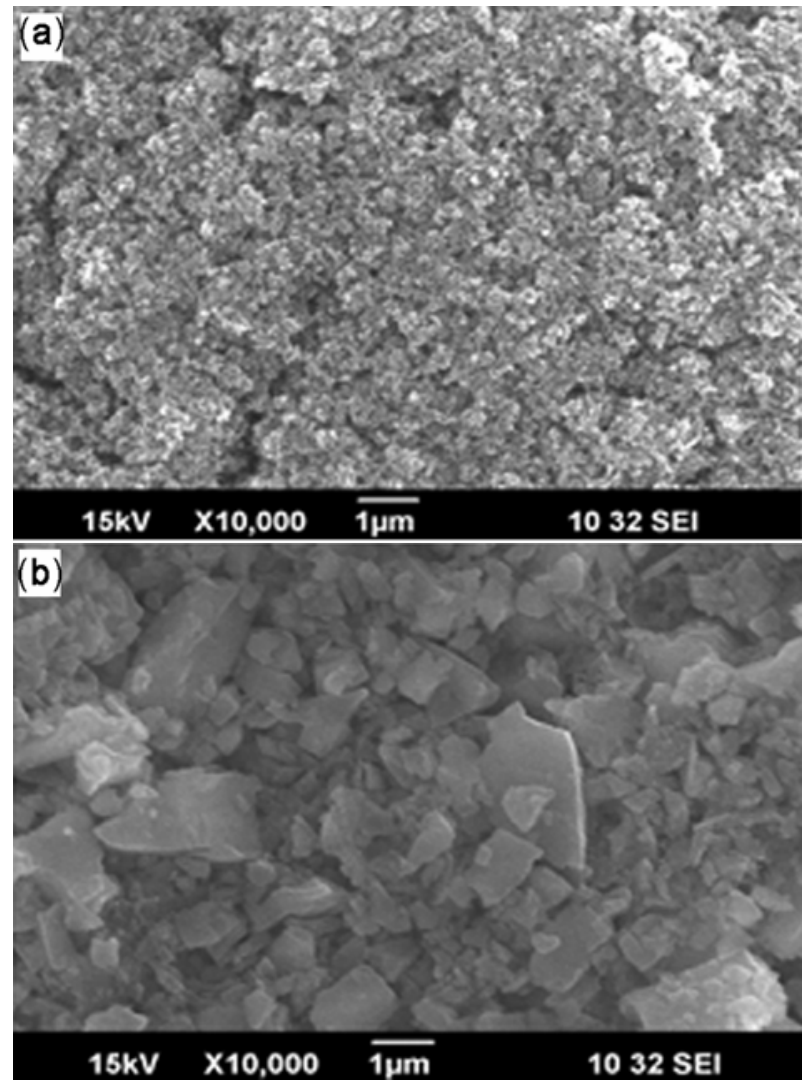

Figure 7. SEM images of (a) mesoporous $\mathrm{TiO}_{2}$ thin film and (b) $\mathrm{Al}_{2} \mathrm{O}_{3}$ : C-coated $\mathrm{TiO}_{2}$ film.

Table 1. HOMO and LUMO values of $\mathrm{TiO}_{2}, \mathrm{ZnO}$ and $\mathrm{Al}_{2} \mathrm{O}_{3}$ by means of cyclic voltammetry.

\begin{tabular}{lcccc}
\hline & $\mathrm{TiO}_{2}$ & $\mathrm{ZnO}$ & $\mathrm{Al}_{2} \mathrm{O}_{3}$ & N719 dye \\
\hline LUMO $(\mathrm{eV})$ & $-3 \cdot 870$ & -1.578 & -2.716 & -3.85 \\
HOMO $(\mathrm{eV})$ & $-7 \cdot 104$ & $-5 \cdot 108$ & -5.81 & -5.45 \\
$E_{\mathrm{g}}(\mathrm{eV})$ & 3.234 & 3.53 & 3.094 & \\
\hline
\end{tabular}


Table 2. Photovoltaic measurements of $\mathrm{ZnO} / \mathrm{TiO}_{2}$ composite with dye (N719).

\begin{tabular}{llcccc}
\hline $\begin{array}{l}\text { Sample } \\
\text { name }\end{array}$ & \multicolumn{1}{c}{ Cell details } & $V_{\mathrm{oc}}(\mathrm{V})$ & $J_{\mathrm{sc}}\left(\mathrm{mA} / \mathrm{cm}^{2}\right)$ & $\begin{array}{c}\text { Fill factor } \\
(\%)\end{array}$ & $\begin{array}{c}\text { Efficiency } \\
(\%)\end{array}$ \\
\hline $\mathrm{Z1}$ & Pristine & 0.706 & 0.31 & 55 & $0 \cdot 12$ \\
$\mathrm{Z2}$ & 600 cGy (photon beam, 6 MV) & 0.468 & 1 & 29 & $0 \cdot 14$ \\
$\mathrm{Z3}$ & 600 cGy (electron beam, 15 MeV) & 0.5669 & 0.037 & 49.0407 & 0.010 \\
\hline
\end{tabular}

Table 3. Photovoltaic measurements of $\mathrm{ZnO} / \mathrm{TiO}_{2}$ composite without dye.

\begin{tabular}{llcccc}
\hline $\begin{array}{l}\text { Sample } \\
\text { name }\end{array}$ & \multicolumn{1}{c}{ Cell details } & $V_{\mathrm{oc}}(V)$ & $J_{\mathrm{sc}}\left(\mathrm{mA} / \mathrm{cm}^{2}\right)$ & $\begin{array}{c}\text { Fill factor } \\
(\%)\end{array}$ & $\begin{array}{c}\text { Efficiency } \\
(\%)\end{array}$ \\
\hline Z4 & Pristine $(1: 1)$ & 0.634 & 0.603 & 50 & $0 \cdot 19$ \\
Z5 & 600 cGy (Photon beam, 6 MV) & 0.566 & 0.602 & 33 & $0 \cdot 11$ \\
Z6 & 600 cGy (Electron beam, 15 MeV) & 0.527 & 0.044 & 38 & $0 \cdot 009$ \\
\hline
\end{tabular}

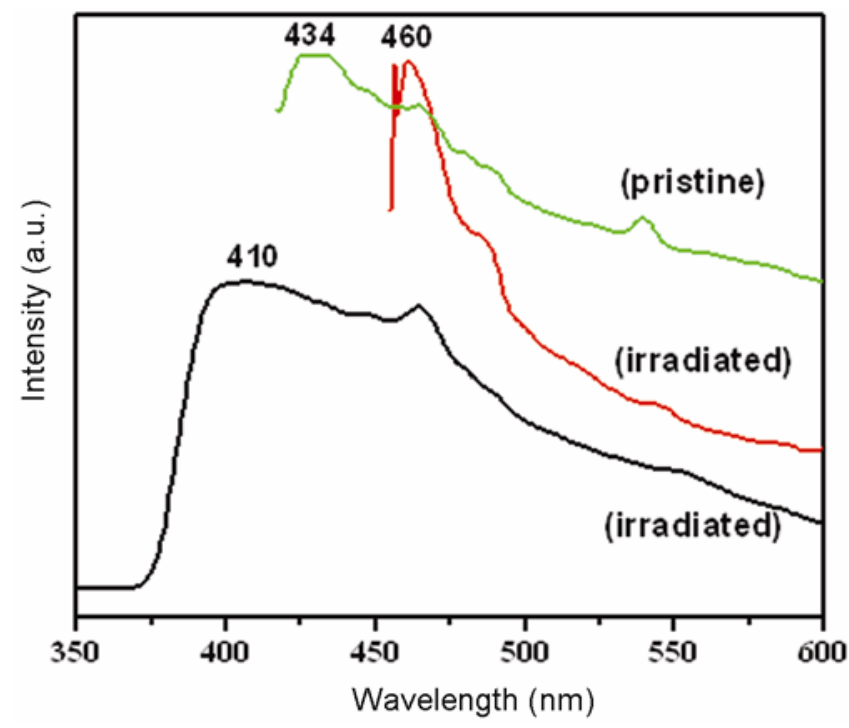

Figure 8. PL spectra of $\mathrm{Al}_{2} \mathrm{O}_{3}: \mathrm{C}$ (a) pristine sample and (b), (c) irradiated samples.

irradiated with $6 \mathrm{MeV}$ photon beam to deliver an absorbed dose of about $600 \mathrm{cGy}$. The peaks at 410 and $461 \mathrm{~nm}$ in PL spectra correspond to $\mathrm{F}$ centre and $\mathrm{F}^{-}$centre, respectively. The main OSL emission in $\mathrm{Al}_{2} \mathrm{O}_{3}: \mathrm{C}$ is due to $F$ centre and $F_{2}^{+}$centres (two oxygen vacancies with three electrons). $F$ centre emission was obtained by excitation using $300 \mathrm{~nm}$ radiation (that corresponds to the $F$ centre's excitation energy). $\mathrm{Al}_{2} \mathrm{O}_{3}$ : C crystals contain a relatively high concentration of oxygen vacancies, $V_{0}$ that provides capture centres for electrons, like $F$-centres in alkali halide crystals. Here, the main emission centres are $F$-centres created by $V_{0}$ defect capturing two electrons, with the emission peak at $\lambda \sim 410 \mathrm{~nm}$. Hence, these results confirm that $\mathrm{Al}_{2} \mathrm{O}_{3}: \mathrm{C}$ thin film shows OSL property.

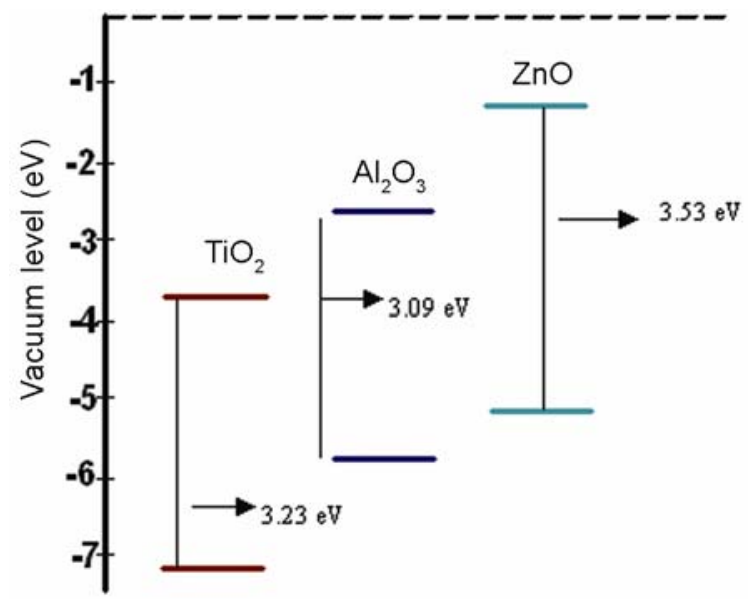

Figure 9. Schematic diagram of the electrochemically determined $\mathrm{HOMO}$ and LUMO of $\mathrm{TiO}_{2}, \mathrm{ZnO}$ and $\mathrm{Al}_{2} \mathrm{O}_{3}$.

Table 1 outlines the band-off set values and bandgap of different semiconductors used for DSSC. The comparison of offset values between different semiconductors reveals that $\mathrm{ZnO}$ and $\mathrm{Al}_{2} \mathrm{O}_{3}$ are more electronegative than $\mathrm{ZnO}$ nanoparticles. Thus, it can be concluded that $\mathrm{ZnO}$ and $\mathrm{Al}_{2} \mathrm{O}_{3}$ can be used an extremely thin absorber (ETA) materials and can easily transfer electron from this ETA to the $\mathrm{TiO}_{2}$ layer leading to an increase in the photocurrent and conversion efficiency. Figure 9 depicts schematically the electrochemically-determined energy levels of $\mathrm{TiO}_{2}$, $\mathrm{ZnO}$ and $\mathrm{Al}_{2} \mathrm{O}_{3}$ on an electrochemical scale. This electron transfer is in addition to the role of the N719 dye, a wellestablished light harvesting organic molecule (Asha et al 2012). The dye, by itself, enhances the light harvesting and electron injection efficiencies of DSSC. DSSC contains thin layer of wide bandgap semiconductors, such as $\mathrm{TiO}_{2}$ or $\mathrm{ZnO}$. A schematic representation of DSSC is shown in figure 10. Its working principle is: (1) the incident photon is absorbed by the dye molecule 


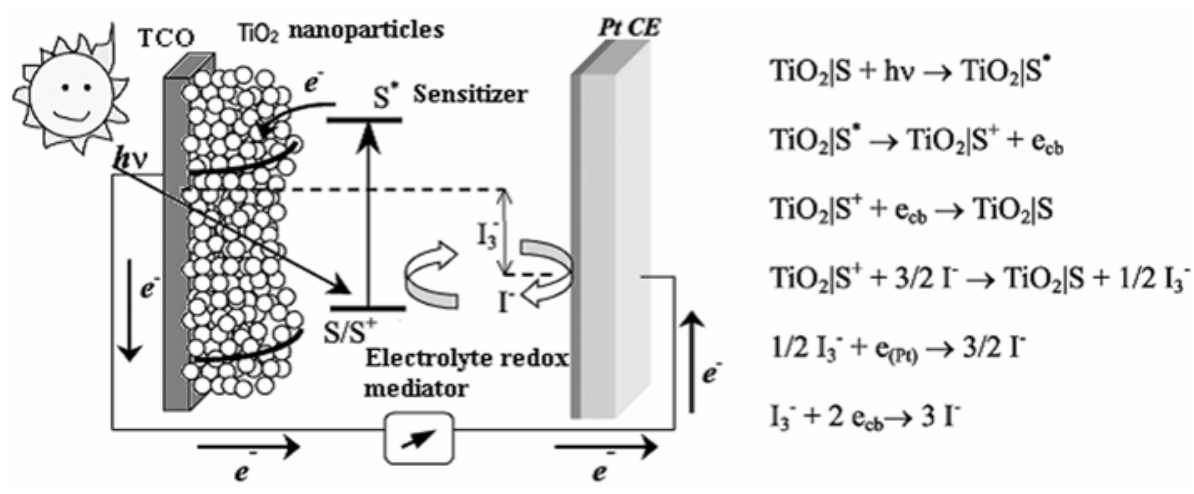

Figure 10. Schematic diagram showing working of DSSC and role of dye.

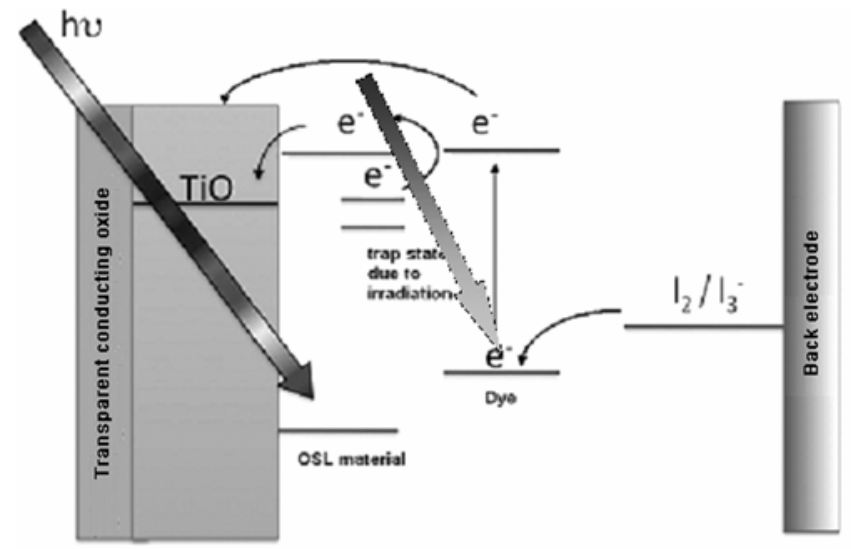

Figure 11. Schematic diagram showing combined action of solid-state absorber and dye in DSSC.

adsorbed on the surface of nanocrystalline $\mathrm{TiO}_{2}$ particles and an electron from the molecular ground state, S0 is excited to an excited state, $\mathrm{S}^{*} ;(2)$ the excited electron of the dye is injected into the conduction band of the $\mathrm{TiO}_{2}$ particles, leaving the dye molecule to an oxidized state, $S$; (3) the injected electron diffuses through the porous nanocrystalline structure to the transparent conducting oxide (TCO) layer of the glass substrate (negative electrode or anode) and finally through an external load to the counter electrode (positive electrode or cathode); (4) at the counter electrode, the electron is transferred to the triiodide $\left(I_{3}^{-}\right)$in electrolyte to yield iodide $\left(I^{-}\right)$and $(5)$ the cycle is closed through reducing the oxidized dye by the iodide in the electrolyte.

Thus, as explained above, both the dye and the solidstate absorber material contribute to the light harvesting and electron injection events thus, increasing the efficiency of the solar cell. The schematic of the combined action of dye and solid-state absorber is shown in figure 11.

For comparison with a conventional photoelectrode composed of dye modified $\mathrm{TiO}_{2}$, four types of DSSC were fabricated and cell performance was compared.
Tables 2 and 3 summarize the cell parameters for the DSSCs fabricated using two types of photo electrodes; $\mathrm{ZnO}$ coated $\mathrm{TiO}_{2}$ dye modified films (table 2) and films without dye molecule (table 3 ).

Open circuit voltage $\left(V_{\mathrm{oc}}\right.$ in $\left.V\right)$, short circuit current $\left(J_{\mathrm{sc}}\right.$ in $\left.\mathrm{mA} / \mathrm{cm}^{2}\right)$, fill factor $(\%)$, efficiency $(\eta \%)$ for sample $\mathrm{Z} 1, \mathrm{Z} 2$ and $\mathrm{Z} 3$ are tabulated. From this table, we can see that the pristine sample $\mathrm{Z} 1$ shows high $V_{\text {oc }}$. This can be because of $\mathrm{ZnO}$ acting as the barrier layer since, it is OSL inactive. Among the irradiated samples, Z2 irradiated using $6 \mathrm{MV}$ photon beam showed the maximum efficiency, $J_{\mathrm{sc}}$ is increased to $1 \mathrm{~mA} / \mathrm{cm}^{2}$. It is assumed that this irradiation is not creating any new trap centres in the material. Instead, it populates the existing trap centres near the conduction band and upon illumination; the carriers will be injected on to $\mathrm{TiO}_{2}$, which helps to increase the photocurrent. Also, cracks in the $\mathrm{ZnO}$ film can bring dye in direct contact with $\mathrm{TiO}_{2}$ and contribute to photocurrent. However, there is a slight decrease in the open circuit voltage. But for Z3 sample, which was irradiated with $15 \mathrm{MeV}$ electron beam, the photo current was low. Upon irradiation with the electron beam, radiationinduced trap centres are formed which are deep in the energy gap and the electrons in this trap centre have less probability to be excited to the conduction band and hence, not contributing to the photocurrent.

On comparing with table 2 , it is seen that the efficiency is larger for the pristine structures in cell structure without dye molecule (see table 3 ). From the $\mathrm{C}-\mathrm{V}$ studies the LUMO of the dye was found to be lying below the conduction band of $\mathrm{ZnO}$, which prevents the injection of electrons from dye to $\mathrm{ZnO}$. In the case of samples without dye, the electrons from both the conduction band and trap centres below it can easily flow to the conduction band of $\mathrm{TiO}_{2}$ and hence, there is an improvement in the photocurrent for these samples. For $600 \mathrm{cGy}(15 \mathrm{MeV})$ sample, which was irradiated with $15 \mathrm{MeV}$ electron beam, the photo current was low. Upon irradiation with the electron beam radiation induced trap centres are formed which are deep in the energy gap and the electrons in this trap centre have less probability to be excited 
Table 4. Photovoltaic measurements of $\mathrm{Al}_{2} \mathrm{O}_{3}: \mathrm{C} / \mathrm{TiO}_{2}$ composite with $\mathrm{N} 719$ dye.

\begin{tabular}{llcccc}
\hline $\begin{array}{l}\text { Sample } \\
\text { name }\end{array}$ & Cell details & $V_{\mathrm{oc}}(\mathrm{V})$ & $J_{\mathrm{sc}}\left(\mathrm{mA} / \mathrm{cm}^{2}\right)$ & $\begin{array}{c}\text { Fill factor } \\
(\%)\end{array}$ & $\begin{array}{c}\text { Efficiency } \\
(\%)\end{array}$ \\
\hline A1 & Pristine & 0.487 & $0 \cdot 149$ & 32 & $0 \cdot 02$ \\
A2 & $600 \mathrm{cGy}(6 \mathrm{MV})$ & $0 \cdot 766$ & 0.528 & 59 & 0.24 \\
A3 & $500 \mathrm{cGy}(6 \mathrm{MV})$ & 0.528 & 0.052 & 39 & 0.01 \\
\hline
\end{tabular}

Table 5. Photovoltaic measurements of $\mathrm{Al}_{2} \mathrm{O}_{3}: \mathrm{C} / \mathrm{TiO}_{2}$ composite without dye.

\begin{tabular}{llcccc}
\hline $\begin{array}{l}\text { Sample } \\
\text { name }\end{array}$ & Cell details & $V_{\mathrm{oc}}(\mathrm{V})$ & $J_{\mathrm{sc}}\left(\mathrm{mA} / \mathrm{cm}^{2}\right)$ & $\begin{array}{c}\text { Fill factor } \\
(\%)\end{array}$ & $\begin{array}{c}\text { Efficiency } \\
(\%)\end{array}$ \\
\hline A4 & Pristine & 0.476 & 0.033 & 23 & 0.004 \\
A5 & 600 cGy (6 MV) & 0.488 & 0.745 & 28 & 0.102 \\
A6 & 500 cGy (6 MV) & 0.402 & 0.181 & 30 & 0.022 \\
\hline
\end{tabular}

to the conduction band and hence, not contributing to the photocurrent.

The cell parameters for $\mathrm{Al}_{2} \mathrm{O}_{3}: \mathrm{C} / \mathrm{TiO}_{2}$ photoanode are shown in tables 4 and 5 . From the table 4 , it is clear that the conversion efficiency was larger for the sample A2, which was irradiated with $6 \mathrm{MV}$ photon beam with an absorbed dose of $600 \mathrm{cGy}$, which can be attributed to the increased OSL property of this sample after irradiation. For sample A3, absorbed dose was insufficient to fill the trap levels.

On comparing with table 4, the efficiency was observed to be lower for the samples without dye (see table 5). As the $\mathrm{Al}_{2} \mathrm{O}_{3}$ : C layer is porous; some of the dye molecules can penetrate through and get into contact with the $\mathrm{TiO}_{2}$ layer. Upon illumination, electrons from the LUMO of these dye molecules can move to the conduction band of $\mathrm{TiO}_{2}$. This is in addition to electrons injected from the OSL material. This can be taken as the reason for the improved performance of the cell in presence of the dye. Thus, from the current-voltage analysis of the solar cells, DSSC based on the $\mathrm{ZnO} / \mathrm{TiO}_{2}$ composite electrode gained a $J_{\mathrm{sc}}$ of about $1 \mathrm{~mA} / \mathrm{cm}^{2}$ with $\mathrm{N} 719$ dye and efficiency of $0 \cdot 14 \%$, whereas for $\mathrm{Al}_{2} \mathrm{O}_{3}: \mathrm{C} / \mathrm{TiO}_{2}$ photoanode structure, the current density was $0.528 \mathrm{~mA} /$ $\mathrm{cm}^{2}$ with $\mathrm{N} 719$ dye with an efficiency of $0.24 \%$. The solar cell efficiency values are low and could be due to the $\mathrm{TiO}_{2}$ layer of the photoanode having inadequate porosity and consequent low dye intake. Recently, our group has attained an efficiency of $7.6 \%$ with an optimized photoanode composed of electrospun $\mathrm{TiO}_{2}$ fibres having embedded graphene (Asha et al 2012). Incorporation of these solid-state absorber layers into this optimized photoanode is expected to lead to further improvements.

\section{Conclusions}

In this work, we present experimental evidence of using OSL materials like $\mathrm{ZnO}$ and $\mathrm{Al}_{2} \mathrm{O}_{3}: \mathrm{C}$ as an extremely thin solid-state absorber layer in DSSC structure. These nanophosphors were obtained by a simple wet chemical method. Solar cell was fabricated with $\mathrm{ITO} / \mathrm{TiO}_{2} / \mathrm{ZnO}$ and $\mathrm{ITO} / \mathrm{TiO}_{2} / \mathrm{Al}_{2} \mathrm{O}_{3}: \mathrm{C}$ as photoanodes with and without incorporating dye molecule. For $\mathrm{ITO} / \mathrm{TiO}_{2} / \mathrm{ZnO}$ photoelectrode system, it is assumed that the irradiation fills the trap centres in the $\mathrm{ZnO}$, which are injected to the conduction band of $\mathrm{TiO}_{2}$ upon illumination under AM 1.5 conditions. This process resulted in an increase in photocurrent and hence in the efficiency. For ITO/TiO $/$ $\mathrm{Al}_{2} \mathrm{O}_{3}$ : C photoanode, apart from irradiation effects, the $\mathrm{Al}_{2} \mathrm{O}_{3}: \mathrm{C}$ is porous and hence, there is a possibility for the dye molecules to diffuse through this layer and reach $\mathrm{TiO}_{2}$ and this may be the reason for the improved performance. Both $\mathrm{ZnO}$ and $\mathrm{Al}_{2} \mathrm{O}_{3}$ : C can be used as solid-state absorbers in conjunction with the dye. On comparing both the dye loaded photoanodes $\left(\mathrm{ZnO} / \mathrm{TiO}_{2}\right.$ and $\mathrm{Al}_{2} \mathrm{O}_{3}: \mathrm{C} / \mathrm{TiO}_{2}$ ), it can be concluded from the present studies that the $\mathrm{Al}_{2} \mathrm{O}_{3}: \mathrm{C}$ is superior to $\mathrm{ZnO}$ under photon irradiation. $\mathrm{Al}_{2} \mathrm{O}_{3}: \mathrm{C}$ is more sensitive to photon irradiation than $\mathrm{ZnO}$ and hence, there can be more trap centres produced in $\mathrm{Al}_{2} \mathrm{O}_{3}: \mathrm{C}$. But, further optimizations in the film thickness and irradiation condition (varying the energy and dosage) are needed to enhance the efficiency. Doping the $\mathrm{ZnO}$ will also produce additional trap centres, which will improve the OSL phenomenon.

\section{Acknowledgements}

The authors acknowledge the Department of Science and Technology, the Government of India for supporting this work. The authors acknowledge the technical help, discussions and assistance for the irradiation experiments from Mr Rajaneesh Kumar and Dr Bhaskaran Pillai, Department of Radiation Oncology, AIMS, Cochin. The authors are also very grateful to Amrita Institute of Medical Sciences (AIMS), for infrastructure support to this programme. 


\section{References}

Asha A M, Sujith K, Chacko D K, Arun T A, Sivakumar N, Subramanian K R V, Nair A S, Nair S V and Avinash B 2012 RSC Advances 213032

Cruz-Vaquez C and Burruel-Ibarra S E 2007 Radiat. Effects \& Defects Solids 162737

Fabregat-Santiago F, Bisquert J and Grätzel M $2009 \mathrm{~J}$. Am. Chem. Soc. 131558

Ghada I K, Larissa L and Harnik S 2008 ACS Nano 2833

Gopal K M, Oomman K V and Maggie P 2006 Solar Energy Mater. \& Solar Cells 9075
Grätzel M 2003 J. Photochem. Photobiol, C Photochem. Rev. 4 145

Li S-L, Jiang A K-J and Shaoab K-F 2006 Chem. Commun. 2792

Luque A and Martin A 1997 Phys. Rev. Lett. 785014

Nozik A J 2002 Physica E14 115

O'Regan B and Grätzel M 1991 Nature 353737

Pradhan A S and Lee J I 2008 J. Med. Phys. 3385

Schaller R D and Klimov V I 2004 Phys. Rev. Lett. 92 186601

Schembri V and Heijmen B J M 2007 J. Med. Phys. 34 2113 